\title{
Late Holocene shorelines at the Gulf of Aqaba: migrating shorelines under conditions of tectonic and sea level stability
}

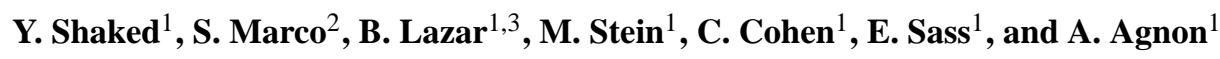 \\ ${ }^{1}$ Institute of Earth Sciences, The Hebrew University, Jerusalem 91904, Israel \\ ${ }^{2}$ Geological Survey of Israel, 30 Malkhe Israel st., Jerusalem 95501, Israel, (present address: Department of Geophysics and \\ Planetary Sciences, Tel Aviv University, Ramat Aviv, Tel Aviv 69978, Israel) \\ ${ }^{3}$ Interuniversity Institute for Marine Sciences, POB 469, Elat, Israel
}

Received: 16 October 2000 - Revised: 21 January 2002 - Accepted: 29 January 2002

\begin{abstract}
The Gulf of Aqaba (Elat) is a developing rift at the southern end of the Dead Sea Transform system. Studying fossil shorelines (coral reef terraces and beach rocks) we obtain constraints on the evolution of the gulf's coastal margin. Fossil reefs at the gulf indicate that during the past 6000 years sea level was relatively stable, and regional vertical tectonic movements were negligible. Nevertheless, south of Elat (NW corner of the gulf) we find that the shoreline has migrated seaward by more than $100 \mathrm{~m}$, through accumulation of coarse clastic sediments. In the absence of a fluvial feeder at the location of the migrating shoreline, we suggest that long-shore processes transported the sediment.

Our observations include sedimentary structures from two trenches dug in beach sediments, buried and emerged fossil reefs, and the local submarine slope morphology. We consider the regional Holocene climate and Holocene vertical displacements in the gulf, and infer that the eastward propagation of the shoreline reflects a delayed response to tectonic changes in coastal bathymetry or the result of climatic events.
\end{abstract}

\section{Introduction}

The Gulf of Aqaba (Elat) occupies the southernmost $180 \mathrm{~km}$ of the Dead Sea transform system (Fig. 1). It is generally accepted that left lateral slip of $\sim 105 \mathrm{~km}$ occurred across the Dead Sea plate boundary system since its initiation $\sim 18 \mathrm{Ma}$ (e.g. Joffe and Garfunkel, 1987; Girdler, 1990). Strike-slip motions are recognized well into Quaternary and even historical times (Amit et al., 1999, Garfunkel, 1970; Ellenblum et al., 1998). The gulf has existed, perhaps intermittently, during the past $\sim 7 \mathrm{Ma}$ (Garfunkel et al., 1974). The de-

Correspondence to: Y. Shaked (yonathan@vms.huji.ac.il) velopment of a gulf cutting through the surrounding highelevation terrain calls for substantial vertical tectonic motions, and these are probably the dominant factors controlling the shape of the gulf. On a finer spatial and temporal scale the shoreline is a result of various sedimentary processes such as sediment transport to the gulf, transport of sediments along the shores, growth of massive coral reefs, and cementation of beach sediments to form beachrocks. These latter processes are often affected by local climate and sea level changes.

Floods are the main agents transporting eroded material from the surrounding exposed crystalline basement into the gulf in this arid region. At the mouths of catchment basins alluvial fans develop, and offshore from large Wadi mouths submarine fans shape the slope. Along the shoreline sediments are transported by beach-drift driven by the dominant (95\% of the time) north-wind driven waves oblique to the shores, and by heavy southern storms that occur several times a year. Beachrocks are exposed along many of the shores, forming 1-3 $\mathrm{m}$ wide strips at the shoreline. They are cemented by calcium carbonate and the clasts are similar to the present-day loose beach sediments varying in size from millimeter scale to a few centimeters. Beachrocks have also been found buried by loose sediments at many construction sites along the shore at Elat.

Since the Last Glacial Maximum ( $\sim 20 \mathrm{ka}$ ) global sea level rose rapidly, and by $\sim 7 \mathrm{ka}$ most of the glacial water has been discharged to the oceans (Shackleton and Opdyke, 1973; Fairbanks, 1989; Nakada et al., 2000; Yokoyama et al., 2000). Sea level indicators at locations around the world and glacio-hydro-isostatic models show that the pattern of relative sea level rise during the Middle and Late Holocene was not uniform in time and space, but rather depends on the proximity to the melting ice sheets and local tectonics (Pirazzoli, 1991; Lambeck and Nakada, 1992; Eisenhauer 


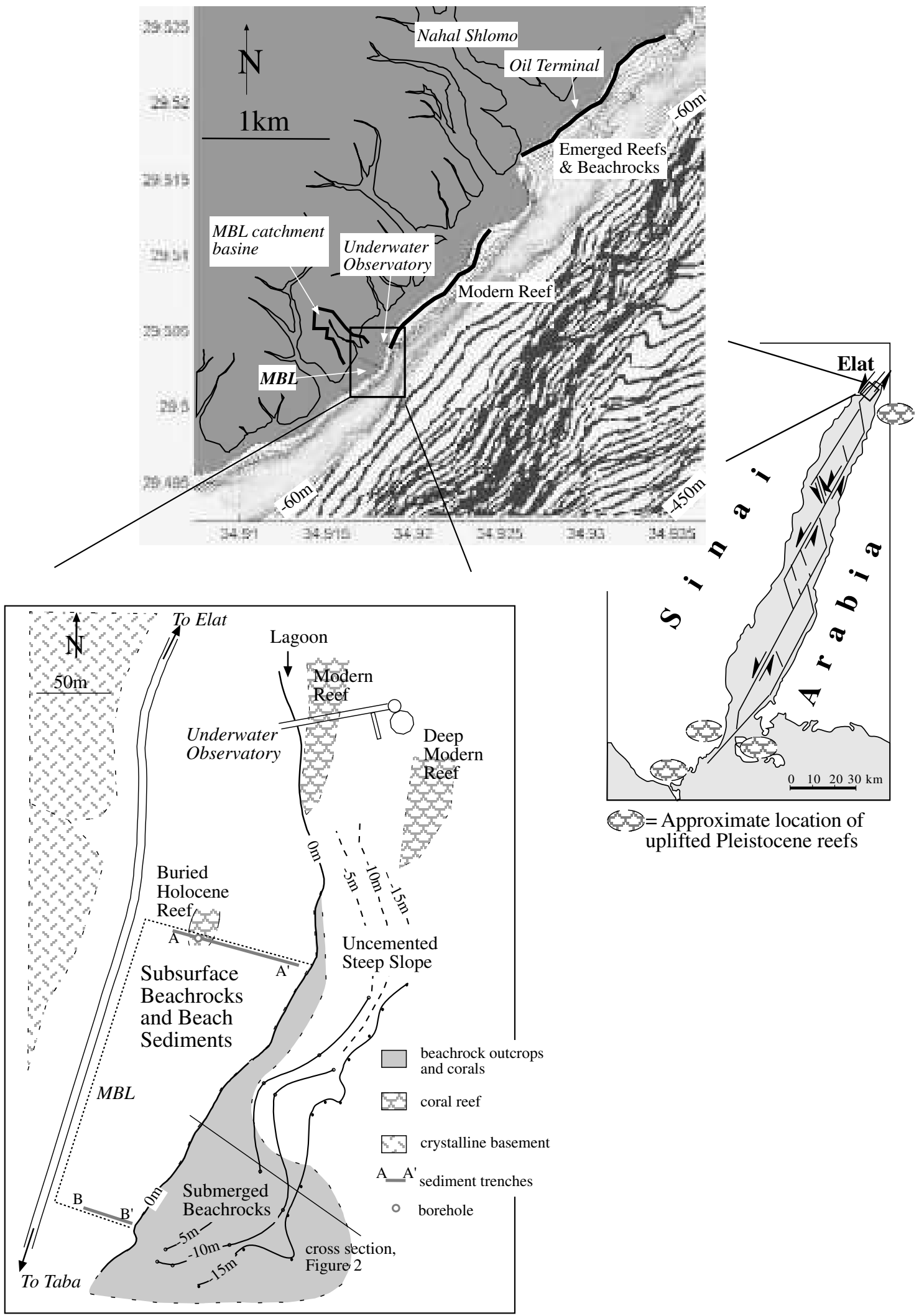

Fig. 1. Location map with approximate locations of uplifted fossil coral reefs. Tectonic model of the gulf after Ben-Avraham et al. (1979), Ben-Avraham (1985). Map of the northwestern shore of the gulf and the northwestern slope. Shown are the locations of sediment trenches (A-A', B-B'), borehole, and emerged and buried reefs discussed in the text. Location of the slope cross-section of Fig. 2. Deep slope bathymetry from Ben-Avraham and Tibor (1993). Shallow high-resolution bathymetry collected by M. Reidenbach, D. Fong, A. Genin, G. Yahel, Y. Shaked, A. Agnon (July 2000). 


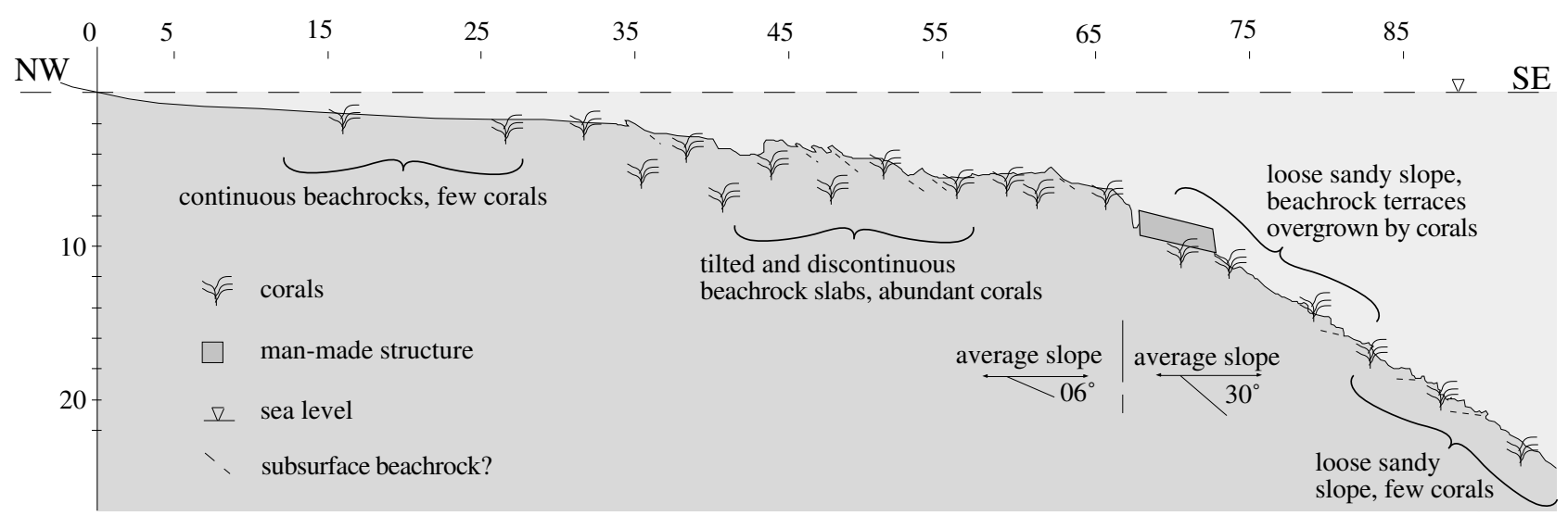

Fig. 2. Cross section of the south-facing underwater slope off the MBL showing the transition from low angle slope of beachrock at shallow depth to a high angle slope with outcropping beachrock slabs at greater depth.

Table 1. Percent of lithic components of beach sediments at MBL

\begin{tabular}{lcccccccc}
\hline $\begin{array}{l}\text { Location } \\
\text { (clast size) }\end{array}$ & chert & $\begin{array}{l}\text { lime- } \\
\text { stone }\end{array}$ & rhyolite & granite & $\begin{array}{c}\text { schist/ } \\
\text { gneiss }\end{array}$ & $\begin{array}{c}\text { marine } \\
\text { biogenic } \\
\text { fragments }\end{array}$ & others & $\mathrm{n}$ \\
\hline back trough $(\sim 2 \mathrm{~cm})$ & 4 & 12 & 17 & 31 & 17 & 16 & 5 & 282 \\
ridge front $(\sim 5 \mathrm{~cm})$ & 4 & 5 & 21 & 40 & 21 & 3 & 6 & 268 \\
ridge front $(\sim 5 \mathrm{~cm})$ & 4 & 12 & 21 & 40 & 19 & 2 & 2 & 341 \\
\hline
\end{tabular}

et al., 1993). In places of complex crustal and tectonic setting such as the Gulf of Aqaba, local sea-level indicators are especially needed to establish the sea level history. The coral reefs along the shores of the Gulf of Aqaba are excellent sea level indicators. Numerous uplifted fossil reefs are exposed near the shores of the gulf at the southern end of Sinai, and the northeastern corner south of the town of Aqaba (Fig. 1). These are Pleistocene reefs that formed during sea level high stands and reached their present position as a result of sea level fluctuations and tectonic uplift (Al-Rifaiy and Cherif, 1988; Gvirtzman et al., 1992; El-Asmar, 1997; Strasser and Strohmenger, 1997). Uplifted Pleistocene reefs are not found on the northwestern shores of the gulf, but a fossil reef slightly above the sea level near Elat was dated by Friedman (1965) at $4.7 \mathrm{ka}$. Reefs of similar age are found at similar elevations along the southern coast of Sinai (Gvirtzman et al., 1992; Gvirtzman, 1994) and the coast of Aqaba (Al-Rifaiy and Cherif, 1988).

In this study we investigate a stretch of the coast south of Elat (Fig. 1), where clastic sediments have accumulated on the shoreline with no apparent fluvial source. This sedimentary bulge seems to prevent the fringing reef of Elat from developing to the south, indicating that it is a recent or still active feature. To determine the processes involved in the formation of the sedimentary bulge we examined the sub aerial and underwater morphology at the site, and dug two long trenches in the sediments, perpendicular to the sea. Evidence of a fossil reef buried beneath the sediments provides further constraints on the origin of this coastal peculiarity.

\section{Observations}

\subsection{Setting of the present-day shoreline}

The modern reef of Elat (Nature Reserve Reef, NRR) stretches continuously along the shore for more than $1 \mathrm{~km}$. To the south, the reef ends abruptly at the fan-like bulge of the Elat underwater observatory (Fig. 1) that is not linked to any present day Wadi mouth. Where the southernmost part of the NRR ends, the underwater slope of the fan-like bulge is steep $\left(30^{\circ}\right)$ and is composed of uncemented terrigenous cobbles and pebbles, and carbonate sands. There are no beachrock outcrops on the shoreline of this stretch. Southwards of the Marine biology Laboratory of Elat (MBL), the south-facing part of the bulge is less steep $\left(6^{\circ}\right)$ and is composed of strips and patches of submerged beachrock overgrown by corals to a depth of $22 \mathrm{~m}$ (Fig. 2). The edge of the modern beachrock horizon lies at the top of this beachrock sequence. At present, the north-facing slope of the bulge accumulates sediments, while the south-facing slope is undergoing erosion. It seems likely that sediment instability or accumulation at the north-facing slope limits the southern development of the modern reef. 


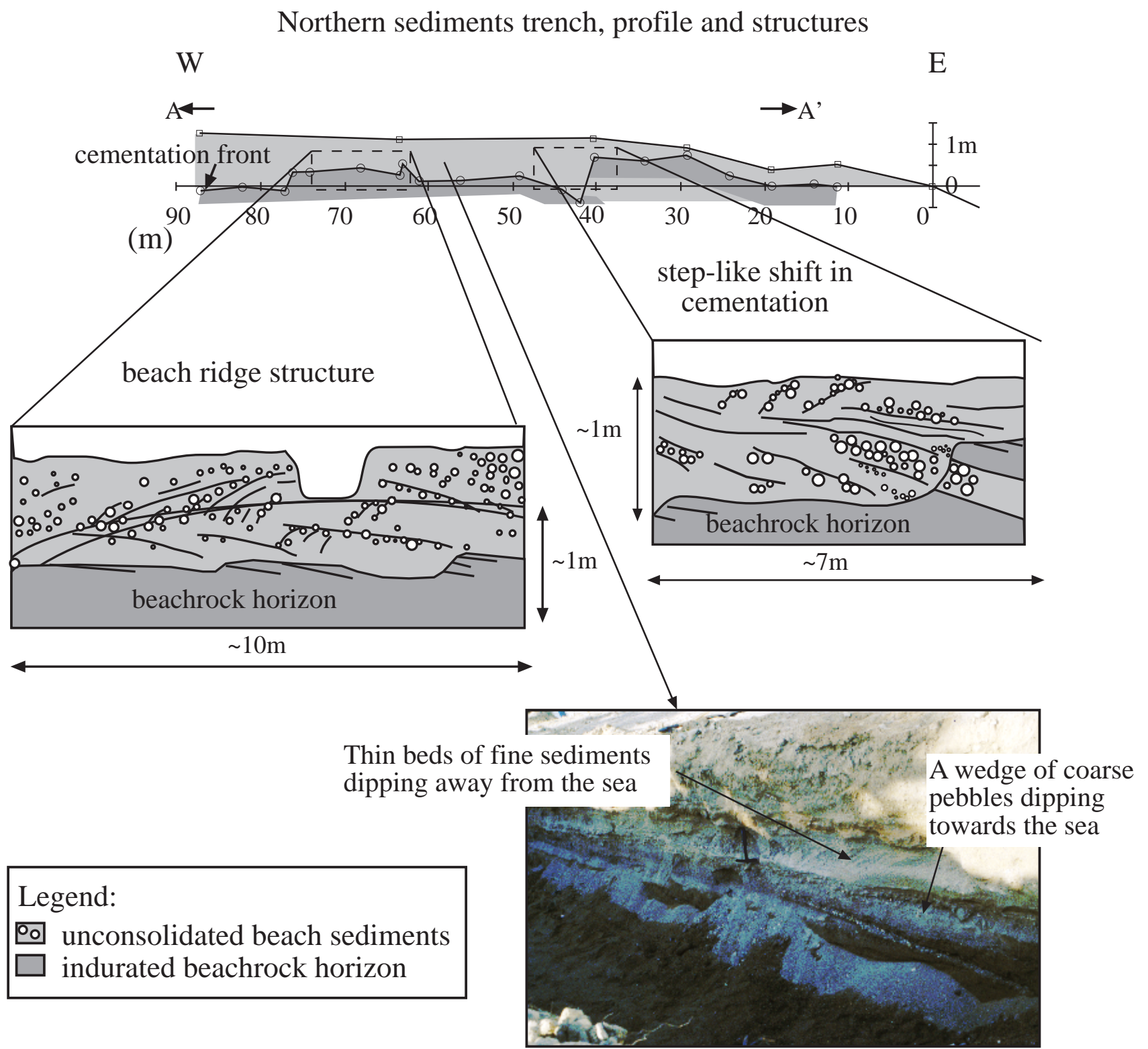

Fig. 3. Profile of the northern sediments trench at the MBL, with a 1:5 vertical exaggeration. Shown in detail are the depositional structures of beach ridges, and the relations between bedding and the cemented horizon. At the bottom photo, a geological hammer is shown for scale. For location see A-A' at Figs. 1 and 4.

\subsection{Beachrocks and beach sediments}

We dug two trenches, $\sim 90 \mathrm{~m}$ and $\sim 40 \mathrm{~m}$ long, on the northern and southern edges of the MBL respectively (Fig. 1), to study the sediments of the fan-like bulge. The sedimentary pile at the MBL is composed mainly of terrigenous crystalline and (fewer) sedimentary clasts, marine shells and coral fragments (Table 1). Structures within the pile include beds dipping both seaward and landward, local features of cross-bedding and graded bedding of individual beds, wedges of coarse pebbles within finer sediments, and locally flat imbricated pebbles (Fig. 3). This pile represents a coastal sequence of beach ridges and channels extend- ing more than $100 \mathrm{~m}$ landward from the present-day shoreline. Beneath the upper loose sediment cover the trenches revealed a horizontal beachrock layer stretching westward (inland) from the shoreline. We found that the beachrocks form a continuous, slightly undulating horizontal layer, up to $1 \mathrm{~m}$ thick, under the topmost few meters of loose sediments (Fig. 4). The cemented horizon grades upward in the following order: indurated beachrock, weakly cemented sediments, clasts coated by aragonite needles, and finally loose uncemented sediments. The indurated layer cuts across the sedimentary structures of individual clastic beds with a depositional dip of $4-12^{\circ}$ (Fig. 3), indicating that a horizontal cementation front was superposed over pre-existing deposi- 


\section{Schematic cross section parallel to the northern trench}

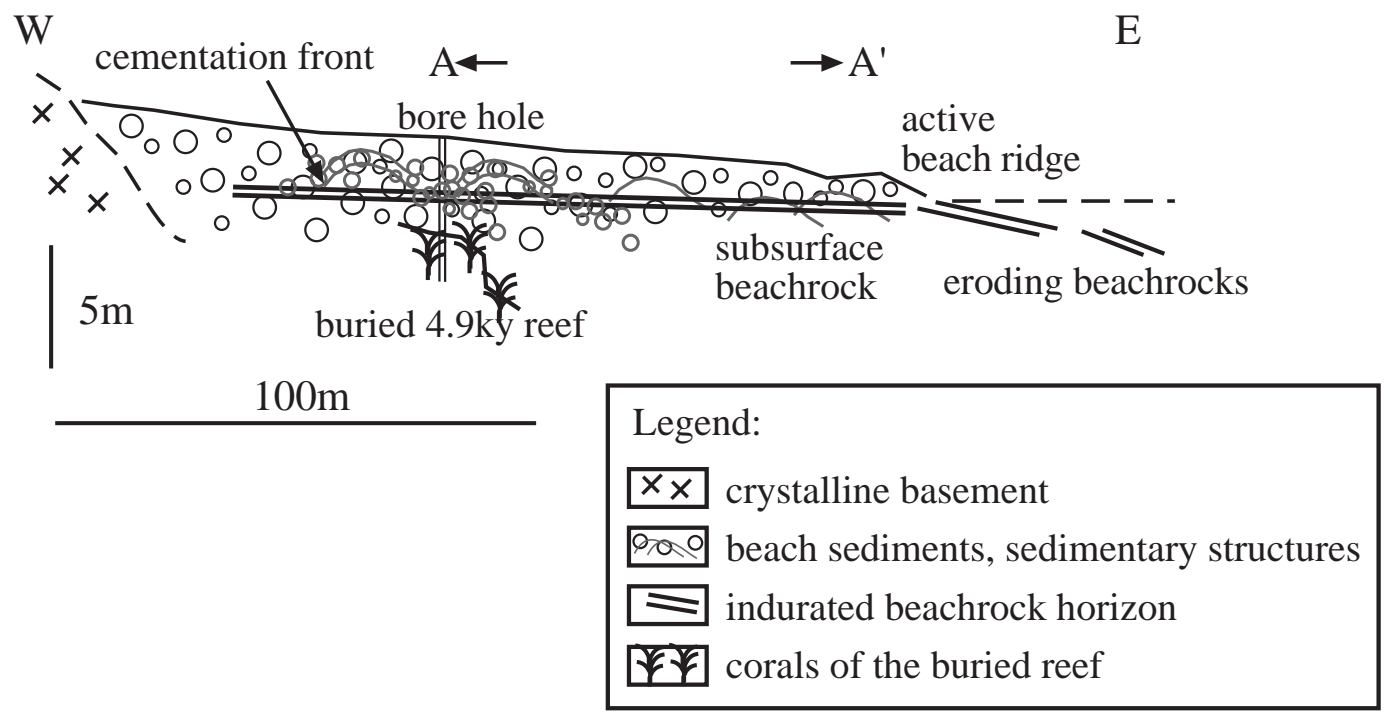

Fig. 4. Schematic cross section of the northern sediment trench at the MBL. Profile showing cross cutting relations between beach sediments, beachrocks, and the buried $4.9 \mathrm{ky}$ reef. Eroding beachrock at the eastern edge is the exposed continuation of the subsurface beachrock plate. For location see A-A' at Fig. 1. For details, A-A' at Fig. 3.

tional structures. During high tide, water rises through the sediments and almost to the cementation front, and during low tide the water-table drops beneath the beachrock horizon. Water salinity over the beachrock horizon within the trenches decreases landward in high tide. Subtle water stratification is observed, with water of slightly lower salinity overlying more saline water. Two radiocarbon ages determined on cements from the beachrock horizon are $3380 \pm 45$ and $2705 \pm 40 \mathrm{yr}$ BP.

\subsection{Buried Holocene reef}

Under the MBL beach sediments, 90-100 m west of the present shoreline, a fossil reef (Fig. 1) was discovered during construction works. The reef was sampled by drilling a borehole at the MBL (Fig. 4), and by collecting samples from construction pits. It extends north of the MBL at least a few hundred meters as revealed by construction works. The fossil reef was dated by U-Th to be $4.9 \mathrm{ka}$ (Enmar, 2000). Radiocarbon ages ranging from 4450 to 5750 years BP were measured by Moustafa et al. (2000) on loose coral samples, reported by them to be approximately $2 \mathrm{~m}$ above the present sea level. The reef is very well preserved mineralogically and texturally under the sedimentary cover even to the finest details such as the delicate septa of massive and branched corals. This most probably indicates rapid burial of the reef with virtually no submarine or sub aerial erosion. Precise elevation determinations are not available, but the age of the reef and its presence above sea level correlate it with the emerged reefs at the present high tide level (exposed during low tide and are covered by waves during high tide) found over long stretches of the coast north of the MBL and south of Aqaba. The well-preserved aragonite composition of corals from the buried reef indicates that it was never elevated above the seawater phreatic zone.

\section{Discussion}

The evidence revealed by the trenches at the MBL imply that in-situ cementation of the beachrocks occurs at the intertidal level within the sedimentary pile after deposition. The intertidal zone in the subsurface is characterized by mixing between seawater and fresh groundwater, which seemingly provides the conditions for cementation. This is supported by the hydrochemistry and petrography of the beachrocks at the MBL (Cohen et al., 2000). Since beachrocks in Elat form at the intertidal level they may be used as datum lines in studies of paleo-sea levels, but do not represent the position of the paleo-shoreline (Cohen et al., 2000). On the contrary: beachrocks are lithified within the sedimentary pile on land. Exposed beachrocks are found only where the overlying sediments were removed by coastal erosion. The age of the beachrock horizon shows that the sediments were deposited and stabilized at least $3 \mathrm{kyr}$ ago. When considered together with the $\sim 5 \mathrm{ky}$ old fossil coral reef buried beneath the beachrocks, the data indicate rapid seaward advance of the MBL shoreline during the Late Holocene to form a protruding fan-like bulge into the sea. The source of the sediments is yet unknown, and the widespread outcrops of beachrocks along the Elat shoreline indicate that the present shore is subjected to erosion. 
Holocene sea level rose rapidly from LGM until 6-7 ka, when most of the continental ice sheets have melted (Nakada et al., 2000). The presence of $\sim 5 \mathrm{ka}$ emerged reefs at high tide elevation at several locations along the shores of the gulf (e.g. Al-Rifaiy and Cherif, 1988, Gvirtzman et al., 1992) indicates that 5-6 ka Holocene sea level reached a maximum of $\sim 1 \mathrm{~m}$ above the present sea level. The widespread occurrence of the emerged reefs around the Gulf of Aqaba indicates that vertical tectonic movements did not affect their vicinity during the past $5 \mathrm{ka}$. Although there seems to have been only minor sea level adjustments during that time, we have evidence that the shoreline at the MBL prograded rapidly eastward (seaward) by more than $100 \mathrm{~m}$. We propose that enhanced sediment transport caused the shoreline migration, probably driven by a Mid-Holocene change in the regional climate. Indeed, $\delta^{13} \mathrm{C}$ and $\delta^{1} 8 \mathrm{O}$ analyses of fossil Holocene corals from collected south of Elat show that a change in regional climate occurred $4.9-4.6 \mathrm{k}$ years ago (Moustafa et al., 2000). Until that time the climate was more humid and after that time the climate became arid, similar to the present. Evidence for regional aridity starting $\sim 5 \mathrm{ka}$ is reported in many and diverse independent studies (e.g. Avner et al., 1994; Bar-Matthews et al., 1997; DeMenocal et al., 2000). During the humid Early Holocene, floods may have been more frequent than they are today, and perhaps capable of carrying a larger sediment load. The age determination of the buried Holocene reef indicates that the eastward migration of the MBL shoreline occurred at the time of the climatic change. However, a large drainage system that could supply the large amount of sediments needed to shift the shoreline more than $100 \mathrm{~m}$ does not exist at the MBL. An alternative explanation is that sediment transport patterns were not stable at the gulf during the mid-Holocene due to the slight relative drop in sea level or to a delayed response to sudden changes in shoreline morphology caused by tectonic displacements. If the latter is true, the majority of sediments were transported along the shore rather than from land. Since currents in the gulf are not strong enough to carry pebble size clasts, long shore transportation may have been possible during large storm events, perhaps linked with the afore mentioned climatic change. Thus, the sudden burial of the Holocene reef may have resulted from a tectonic displacement followed by accumulation of sediments over a downfaulted block. There is evidence of recurring recent displacements at the segment to the north of Elat (Amit et al., 1999; Enzel et al., 1996). In order to solve this issue, further examination of the sediments at the MBL, and a search for matching provenance along the shore is required.

\section{Conclusions}

It is our conclusion that even at tectonically active regions like the Dead Sea system, sharp climatic and sediment transport changes - often overlooked on geological timescales - may be most significant when examining the recent history, before the intervention of Man. We found evidence that during the past $\sim 5 \mathrm{ka}$ the northwestern shore of the Gulf of Aqaba has not experienced significant regional vertical tectonic displacements. During this time the sea level has been relatively stable, following a slight drop from a midHolocene maximum. Nonetheless, the shoreline at the MBL has prograded by more than $100 \mathrm{~m}$ since that time, and fastaccumulating sediments buried middle-Holocene coral reefs. The shoreline instability seems to have resulted from sedimentary processes driven by a mid-Holocene climatic change or, perhaps, a response to earlier changes in shoreline geometry caused by tectonic displacements.

Acknowledgements. We thank the Aims Biudeks Foundation and the Israel Ministry of National Infrastructures for supporting this research. The staff of the Interuniversity Institute for Marine Sciences, Elat, and particularly E. David, O. Ben-Shafrut, I. Ayalon, and E. Brokowitz for underwater assistance. The Israel Nature and Parks Authority, and especially D. Zakai of for cooperation and support. E. Ram of the Geological Survey of Israel for assistance in the field. The reviews of E. Zilberman and two anonymous reviewers improved the final version of this manuscript.

\section{References}

Al-Rifaiy, I. A. and Cherif, O. H.: The fossil coral reefs of AlAqaba, Jordan, Facies, 18, 219-230, 1988.

Amit, R., Zilberman, E., Porat, N., and Enzel, Y.: Relief inversion in the Avrona Playa as evidence of large-magnitude historical earthquakes, Southern Arava Valley, Dead Sea Rift, Quaternary Research, 52, 76-91, 1999.

Avner, U., Carmi, I., and Segal, D.: Neoloithic to Bronze Age settlement of the Negev and Sinai in light of radiocarbon dating: a view from the Southern Negev, in: Bar-Yosef, O. and Kra, R. S. (Eds.): Late Quaternary chronology and pleoclimats of the Eastern Mediterranean, Radiocarbon, 265-300, 1994.

Bar-Matthews, M., Ayalon, A., and Kaufman, A.: Late Quaternary paleoclimate in the eastern Mediterranean region from stable isotope analysis of spleothems at Soreq Cava, Israel, Quaternary Research, 47, 155-168, 1997.

Ben-Avraham, Z.: Structural framework of the gulf of Elat (Aqaba), northern Red Sea, Journal of Geophysical Research, 90, 703726, 1985.

Ben-Avraham, Z., Almagor, G., and Garfunkel, Z.: Sediments and structure of the gulf of Elat (Aqaba) - Northern Red Sea, Sedimentary Geology, 23, 239-267, 1979.

Ben-Avraham, Z. and Tibor, G.: The northern edge of the Gulf of Elat, Tectonophysics, 226, 319-331, 1993.

Berman, T.: Numerical model of the circulation at the Gulf of Elat (Ph.D. thesis, Heb., English summary), Hebrew University, pp. 143, 1999.

Cohen, C., Shaked, Y., Sass, E., and Lazar, B.: Beachrocks in Elat as sea level indicators, Israel Geological Society Annual Meeting, Ma'alot, Israel, p. 26, 2000.

DeMenocal, P., Oritz, J., Guilderson, T., Adkins, J., Sarnthein, M., Baker, L., and Yarusinsky, M.: Abrupt onset and termination of the African Humid Period: rapid climate responses to gradual insolation forcing, Quaternary Science Reviews, 19, 347-361, 2000.

Eisenhauer, A., Wasserburg, G. J., Chen, J. H., Bonani, G., Collins, L. B., Zhu, Z. R., and Wyrwoll, K. H.: Holocene sea-level de- 
termination relative to the Australian continent: U/Th (TIMS) and 14C (AMS) dating of coral cores from the Abrolhos Islands, Earth and Planetary Science Letters, 114, 529-547, 1993.

El-Asmar, H. M.: Quaternary isotope stratigraphy and paleoclimate of coral reef terraces, Gulf of Aqaba, South Sinai, Egypt, Quaternary Science Reviews, 16, 911-924, 1997.

Ellenblum, R., Marco, S., Agnon, A., Rockwell, T., and Boas, A.: Crusader castle torn apart by earthquake at dawn, 20 May 1202, Geology, 26, 303-306, 1998.

Enmar, R.: Submarine diagenesis in reef corals-implications for geochemical parameters, (M.Sc. Thesis, Hebrew, English summary), Hebrew University, pp. 102, 2000.

Enzel, Y., Amit, R., Porat, N., Zilberman, E., and Harrison, B. J.: Estimating the ages of fault scarps in the Arava, Israel, Tectonophysics, 253, 305-317, 1996.

Fairbanks, R. G.: A 17 000-year glacio-eustatic sea level record: influence of glacial melting rates on the Younger Dryas event and deep-ocean circulation, Nature, 342, 637-642, 1989.

Friedman, G. M.: A fossil shoreline reef in the Gulf of Elat (Aqaba), Israel Journal of Earth Sciences, 14, 86-90, 1965.

Garfunkel, Z: The tectonics of the western margins of the southern Arava (a contribution to the understanding of rifting), (Ph.D. thesis, Hebrew, English summary). Hebrew University, pp. 204, 1970.

Garfunkel, Z., Bartov, J., Eyal, Y., and Steinitz, G.: Raham Conglomerate - new evidence for Neogene tectonism in the southern part of the Dead Sea Rift, Geological Magazine, 111, 55-64, 1974.

Girdler, R. W.: The Dead Sea transform fault system, Tectonophysics, 180, 1-13, 1990.
Gvirtzman, G.: Fluctuations of sea level during the past 400000 years: the record of Sinai, Egypt (northern Red Sea), Coral Reefs, 13, 203-214, 1994.

Gvirtzman, G., Kronfeld, J., and Buchbinder, B.: Dated coral reefs of southern Sinai (Red Sea) and their implication to late Quaternary sea levels, Marine Geology, 108, 29-37, 1992.

Joffe, S. and Garfunkel, Z.: Plate kinematics of the circum Red Sea - a re-evaluation, Tectonophysics, 141, 5-22, 1987.

Lambeck, K. and Nakada, M.: Constraints on the age and duration of the last interglacial period and on sea-level variations, Nature, 357, 125-128, 1992.

Moustafa, Y. A., Pätzold, J., Loya, Y., and Wefer, G.: Mid-Holocene stable isotope record of corals from the northern Red Sea, International Journal of Earth Sciences, 88, 742-751, 2000.

Nakada, M., Kimura, R., Okuno, J., Moriwaki, K., Miura, H., and Maemoku, H.: Late Pleistocene and Holocene melting history of the Antarctic ice sheet derived from sea-level variations, Marine Geology, 167, 85-103, 2000.

Pirazzoli, P. A.: World atlas of Holocene sea-level changes, Elsevier Oceanography Series, Elsevier, 299 pp, 1991.

Shackleton, N. J. and Opdyke, N. D.: Oxygen isotope and paleomagnetic stratigraphy of equatorial Pacific core V28-238: Oxygen isotope temperatures and ice volumes on a 105 year and 106 year scale, Quaternary Research, 3, 39-55, 1973.

Strasser, A. and Strohmenger, C.: Early diagenesis in Pleistocene coral reefs, southern Sinai, Egypt: response to tectonics, sealevel and climate, Sedimentology, 44, 537-558, 1997.

Yokoyama, Y., Lambeck, K., De Deckker, P., Johnston, P., and Fifield, L. K.: Timing of the Last Glacial Maximum from observed sea-level minima, Nature, 406, 713-716, 2000. 